\title{
VOLTAMMETRIC DETERMINATION OF CEFOTAXIME USING POTASSIUM PEROXOMONOSULFATE
}

\author{
Yu.Yu.Labuzova \\ National University of Pharmacy \\ Key words: voltammetry; cefotaxime; potassium peroxomonosulfate
}

The presented article is devoted to development of a new procedure for quantitative voltammetric determination of Cefotaxime powder for preparing the solution for injection in the form of the corresponding S-oxide in a weak acidic medium using potassium hydrogenperoxomonosulfate $\left(\mathrm{KHSO}_{5}\right)$ as an analytical reagent. Voltammogramms of Cefotaxime S-oxide solutions for different concentrations of cephalosporins have been scanned. There are two peaks on the voltammetric curve of the Cefotaxime S-oxide solution: at $-0.65 \mathrm{~V}$ (that corresponds to potassium peroxomonosulfate) and $-1.3 \mathrm{~V}$ (the peak height was rising proportionally to Cefotaxime concentrations increase) that has been chosen as analytical. The calibration curve method can be easily applied. Linearity has been studied over the drug concentration range from $1 \cdot 10^{-4}$ to $1 \cdot 10^{-3} \mathrm{~mol} \mathrm{~L}^{-1}$. The correlation coefficient is $r=0.999$. Precision and accuracy have been studied by analyzing five replicates of the sample solutions at three concentrations levels. The relative standard deviations calculated were below $1.75 \%, \delta \leq-1.1 \%$ indicating the excellent precision of the procedure proposed. The Limit of Detection (LOD) and the Limit of Quantification (LOQ) were calculated (LOD $=1.2 \cdot 10^{-5} \mathrm{~mol}^{-1}$ and $\left.L O Q=4 \cdot 10^{-5} \mathrm{~mol}^{-1}\right)$. The voltammetric method proposed is sensitive enough, accurate, precise, replicable and linear to enable determination of lower amounts of a drug. These advantages encourage the application of the method in the routine quality control of Cefotaxime in control and research laboratories.

Cefotaxime (CFTM), which structure is presented in Scheme, is the second generation cephalosporin derivative widely used in clinical therapy of severe infections. Chemically, it is (6R,7R,Z)-3-(Acetoxymethyl)7-(2-(2-aminothiazol-4-yl)-2-(methoxyimino)acetamido)8-oxo-5-thia-1-azabicyclo[4.2.0] oct-2-ene-2-carboxylic acid [5].

Extensive literature survey reveals that a lot of analytical methods are reported for analysis of Cefotaxime like HPLC [13, 14], Capillary electrophoresis [6], Spectrophotometry [1, 11, 12] and Spectrofluorimetry [10].

Polarography, especially differential pulse polarography, and other voltammetric techniques become increasingly important when determining compounds of biological and pharmaceutical significance $[8,9]$.

Literature dealing with the electroactivity of cephalosporins and resulting analytical applications can be divided into two parts: papers concerning the direct polarographic activity of cephalosporins and papers dealing with polarography of their degradation products after intensive acidic, or alkaline hydrolysis [2-4, 7]. The main electrode reaction responsible for the direct polarographic activity of cephalosporins has been shown to be reduction of the $\Delta^{3}$ double bond of the cephem nucleus, which is dependent on the presence and nature of the substituent at position 3 [15]. So, Cefotaxime belongs to cephalosporins with a reducible group in the side-chain on $\mathrm{C}-7$ and $\mathrm{R}^{1}$ in $3-\mathrm{CH}_{2} \mathrm{R}^{1}$. But the indirect method of determination of cephalosporins as the corresponding derivatives requires special conditions (heating, intensive alkali or acidic medium) and are long-lasting. It is supposed that the method of cephalosporin deriva- tives produced by S-oxidation reactions determination is more informative. So, voltammetric determination of Cefotaxime by the reaction of S-oxidation by means of potassium peroxomonosulfate in a weak acidic medium was optimized and proposed for the first time.

\section{Materials and Methods}

\section{Reagents and Chemicals}

All materials were of the analytical reagent grade, and the solutions were prepared with double-distilled water. Cefotaxime, powder for injection, $1.000 \mathrm{~g}$, was produced by "Pharmaceutical company "Zdorovie" (Kharkiv, Ukraine) Ltd, batch No. 41008.

Peroxomonosulfate (Sigma-Aldrich) was employed as received. The solution of peroxomonosulfate was prepared by dissolving its potassium salt $\left(\mathrm{K}_{2} \mathrm{SO}_{5} \cdot \mathrm{KHSO}_{5} \cdot \mathrm{K}_{2} \mathrm{SO}_{4}\right)$ in double-distilled water.

\section{Equipment}

Electrochemical behaviour of cefotaxime S-oxide by differential voltammetry using carbositall electrode (CE) (Russia) as an indicating (working) electrode was studied.

Electrochemical measurements were carried out in an ABC-1.1 analyzer (Volta, St. Petersburg) with a threeelectrode scheme by the alternating current mode with the square wave modulation in the potential range of $-0.4 \ldots-1.8 \mathrm{~V}, \mathrm{~W}=1000 \mathrm{rpm}$, amplitude $40 \mathrm{mV}, v=65 \mathrm{~Hz}$. $\mathrm{CE}$ was used as a working and an auxiliary electrode, and $\mathrm{Ag}, \mathrm{AgCl} / \mathrm{KCl}$ (sat) electrode type EVL-1M4 as a reference electrode.

\section{Preparation of Standard Solution}

Standard solution of Cefotaxime $\left(1 \cdot 10^{-2} \mathrm{~mol} \mathrm{~L}^{-1}\right)$ : transfer $47.74 \mathrm{mg}$ of cefotaxime into a $100 \mathrm{~mL}$ volu- 


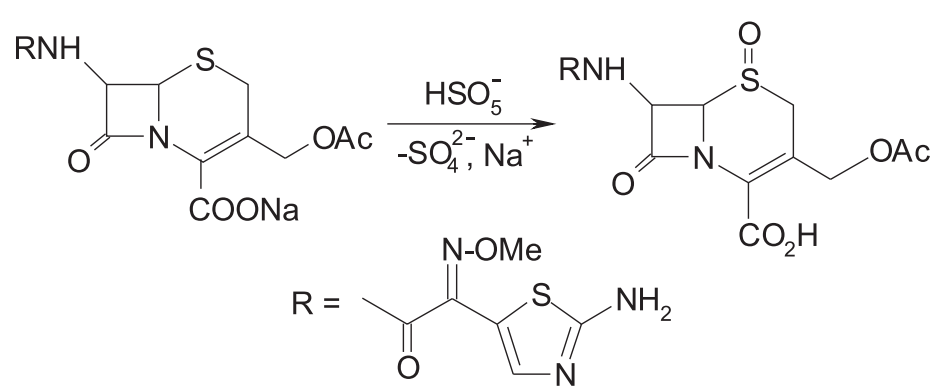

Scheme. The mechanism of Cefotaxime chemical transformations by means of potassium peroxomonosulfate in the acidic medium.

metric flask and dilute to the volume with double distilled water at $293 \mathrm{~K}$.

Standard solution of hydrogenperoxomonosulfate $\left(2 \cdot 10^{-2} \mathrm{~mol} \mathrm{~L}^{-1}\right)$ : transfer $68.30 \mathrm{mg}$ of $2 \mathrm{KHSO}_{5} \cdot \mathrm{KHSO}_{4} \cdot \mathrm{K}_{2} \mathrm{SO}_{4}$ into a $100 \mathrm{~mL}$ volumetric flask and dilute to the volume with double distilled water at $293 \mathrm{~K}$. The solution of peroxomonosulfate was standardized iodometrically.

\section{Procedure}

Pipette aliquots of $0.5-5.00 \mathrm{~mol} \mathrm{~L}^{-1}$ of the Cefotaxime test solutions studied into several $50 \mathrm{~mL}$ volumetric flask containing $3.5 \mathrm{~mL}$ of $0.02 \mathrm{~mol} \mathrm{~L}^{-1} \mathrm{KHSO}_{5}$ solution and $1 \mathrm{~mL}$ of $0.1 \mathrm{~mol} \mathrm{~L}^{-1} \mathrm{Na}_{2} \mathrm{SO}_{4}$ solution $(\mathrm{pH}=3.3)$. Mix the content of each flask well, transfer the electrolyser and record the voltammetric curve.

\section{Results and Discussion}

Cefotaxime is rapidly oxidisable to its sulfoxide in a quantitative yield by the excess of potassium peroxomonosulfate $\left(\mathrm{KHSO}_{5}\right)$ (Scheme). Sulfoxide is reducible at the $\mathrm{CE}$ with the consumption of two electrons.
Voltammogramms of Cefotaxime S-oxide solutions for different concentrations of cephalosporins were scanned. There are two peaks on the voltammetric curve (Fig. 1) of the Cefotaxime S-oxide solution: at $-0.65 \mathrm{~V}$ (that corresponds to potassium peroxomonosulfate) and $-1.3 \mathrm{~V}$ (the peak height was rising proportionally to CFTM concentrations increase). This peak was chosen as the analytical one.

The calibration curve method is simple in procedure, precise and provides a reliable way to calculate the uncertainty of the concentration calculated from the calibration curve (using the statistics of the least squares line fit to the data). These advantages allow to apply the calibration curve method for the assay results calculation (Fig. 2) given in Table.

\section{Linearity}

Linearity was studied over the small drug concentration range from $1 \cdot 10^{-4}$ to $1 \cdot 10^{-3} \mathrm{~mol} \mathrm{~L}^{-1}$. The correlation coefficient $r=0.999$ obtained for the regression

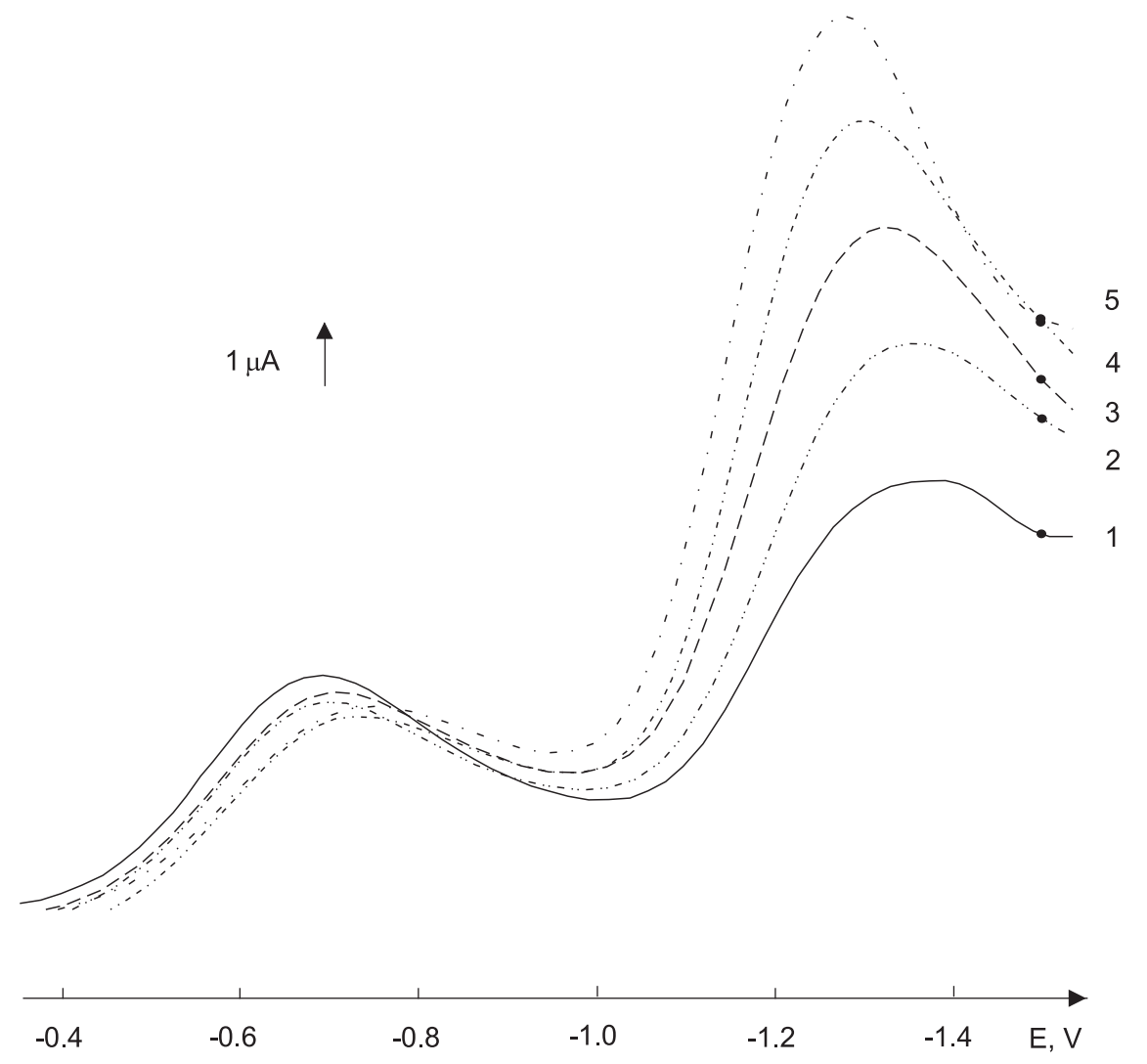

Fig. 1. The voltammetric curve of Cefotaxime S-oxide by means of potassium peroxomonosulfate, $c\left(\mathrm{KHSO}_{5}\right)=0.126 \cdot 10^{-2} \mathrm{~mol}^{-1}$, c (Cefotaxime): $1=2 \cdot 10^{-4}, 2=4 \cdot 10^{-4}, 3=6 \cdot 10^{-4}, 4=8 \cdot 10^{-4}, 5=1 \cdot 10^{-3} \mathrm{~mol} \mathrm{~L}^{-1} ; c\left(\mathrm{Na}_{2} \mathrm{SO}_{4}\right)=0.02 \mathrm{~mol} \mathrm{L-1} ; \mathrm{pH} 3.3$. 
Estimation of accuracy and precision of the initial rate method for determination of Cefotaxime powder for injection

\begin{tabular}{|c|c|c|c|c|}
\hline $\begin{array}{c}\text { Amount taken, } \\
\left(\mathrm{mol} \mathrm{L}^{-1}, 10^{-4}\right)\end{array}$ & $\begin{array}{c}\text { Amount found } \\
\left(\mathrm{mol} \mathrm{L}^{-1}, 10^{-4}\right)\end{array}$ & $\begin{array}{c}\text { Recovery } \\
(\% \pm \mathrm{SD})\end{array}$ & $\mathrm{RSD}(\%)$ & $\delta(\%)$ \\
\hline 3.96 & $3.92 \pm 0.10$ & $98.52 \pm 0.61$ & 1.75 & -1.01 \\
\hline 5.94 & $5.95 \pm 0.12$ & $100.18 \pm 2.00$ & 1.61 & -0.17 \\
\hline 9.90 & $9.84 \pm 0.15$ & $99.37 \pm 1.51$ & 1.22 & -0.63 \\
\hline
\end{tabular}

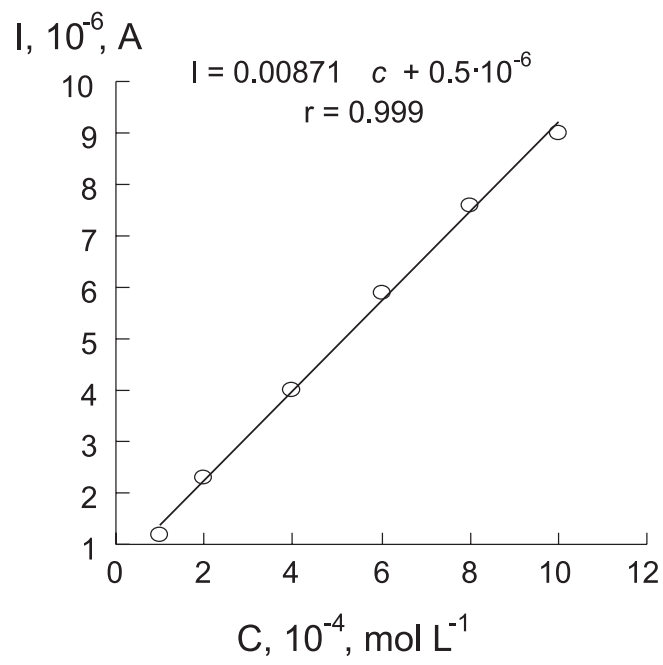

Fig. 2. The calibration graph for voltammetric determination of Cefotaxime in a pure substance. $c\left(\mathrm{KHSO}_{5}\right)=0.126 \cdot 10^{-2} \mathrm{~mol} \mathrm{~L}^{-1}$. $c\left(\mathrm{Na}_{2} \mathrm{SO}_{4}\right)=0.02 \mathrm{~mol} \mathrm{~L}^{-1} ; \mathrm{pH} 3.3$.

line showed a good relationship between the I, $\mu \mathrm{A}$ and the molar concentration of Cefotaxime (Fig. 2).

Accuracy, Precision Limit of Detection and Quantification

The validity of the method proposed was determined by performing recovery studies. Precision and accuracy were studied by analyzing five replicates of the sample solutions at three concentrations levels. The relative standard deviations calculated were all below $1.75 \%$ indicating the excellent precision of the procedure proposed.
The Limit of Detection (LOD) and Limit of Quantification (LOQ) were calculated based on the standard deviation of response and the slope of the calibration curve and expressed as:

$$
\mathrm{LOD}=3 \times S_{a} / b, \mathrm{LOQ}=10 \times S_{a} / b,
$$

where: $S_{a}$ is the standard deviation of the response; $b$ is the slope of the calibration curve.

$\mathrm{LOD}=1.2 \cdot 10^{-5} \mathrm{~mol} \mathrm{~L}^{-1}$ and LOQ $=4 \cdot 10^{-5} \mathrm{~mol} \mathrm{~L}^{-1}$.

The characteristics of the corresponding electrode reaction and its analytical parameters are presented and discussed. Optimum $\mathrm{pH}$-ranges for determination of cefotaxime are given.

\section{CONCLUSIONS}

For the first time voltammetric determination of $\mathrm{Ce}$ fotaxime by the reaction of S-oxidation by means of potassium peroxomonosulfate in a weak acidic medium has been optimized and proposed.

The calibration curve method can be easily applied for determination of Cefotaxime in the powder for injection that does not require the elaborate treatment and expensive materials. The method proposed is sensitive enough to enable determination of lower amounts of a drug; these advantages encourage the application of this method in the routine quality control of Cefotaxime in control and research laboratories. Finally, the method provides advantages of improving selectivity, it is quick and easy in performance.

\section{REFERENCES}

1. Al-Momani I.F. // J. Pharm. Biomed. Anal. - 2001. - Vol. 25. - P. 751-757.

2. Basaez L., Vanysek P. // J. of Pharmac. and Biomed. Analysis. - 1999. - Vol. 19. - P. 183-192.

3. Fogg A.G., Fayad N.M., Burgess C. // Anal. Chim. Acta. - 1979. - Vol. 110. - P. 107-115.

4. Fogg A.G., Fayad N.M., Burgess C., McGlynn A. // Analyt. Chim. Acta. - 1979. - Vol. 108. - P. $205-211$.

5. http://en.wikipedia.org/wiki/Cefotaxime

6. Mrestani Ya., Neubert R.H.H., Härtl A. // Analytica Chimica Acta. - 1997. - Vol. 49. - P. $207-213$.

7. Nuñez-Vergara L.J., Squella J.A., Silva M.M. // Talanta. - 1982. - Vol. 29. - P. 137-138.

8. Ogoverk B., Hudnik V., Gomiscek S. // Frensenius Z. Anal. Chem. - 1988. - Vol. 330. - P. 59-64.

9. Ogoverk B., Gomiscek S. // J. Pharm. and Biomed. Anal. - 1991. - Vol. 9. - P. 225-236.

10. Omar M., Adbelmageed O., Attia T. // Talanta. - 2009. - Vol. 77. - P. 1394-1404.

11. Saleh A., Askal H. // Talanta. - 2001. - Vol. 54. - P. 1205-1215.

12. Samanidou F., Ioannou A.S., Papadoyannis I.N. // J. Chromat. B. - 2003. - Vol. 788. - P. 147-158.

13. Samanidou V.F., Hapeshi E.A., Papadoyannis I.N. // J. Chromat. B. - 2004. - Vol. 809. - P. $175-182$.

14. Zuman P., Kapetanovic V., Aleksic M. // Anal. Lett. - 2000. - Vol. 33. - P. 2821-2857. 


\section{ВОЛЬТАМПЕРОМЕТРИЧНЕ ВИЗНАЧЕННЯ ЦЕФОТАКСИМУ ЗА УЧАСТЮ КАЛЮ ГІДРОГЕНОПЕРОКСОМОНОСУЛЬФАТУ Ю.Ю.Лабузова}

Ключові слова: вольтамперометрія; цефотаксим; калій гідрогенопероксомоносульфат Робота присвячена розробиі нової вольтамперометричної методики кількісного визначення цефотаксиму в порошку для приготування розчину для ін'єкцій за продуктом пероксокислотного окиснення у вигляді S-оксиду в слабкокислому середовищі з використанням калій гідрогенопероксомоносульфату $\left(\mathrm{KHSO}_{5}\right)$ як аналітичного реагента. Були зняті вольтамперограми розчинів S-оксиду цефротаксиму для різних концентрацій цефралоспорину. Катодна гілка вольтамперограми розчину S-оксиду цефотаксиму має два піки: при -0,65 B (що відповідає калій гідрогенопероксомоносульфату) та -1,3 B (висота піку змінювалася пропорційно зміні концентрації цефотаксиму), його обрано як аналітичний. Була показана можливість застосування методу калібрувального графріка. Лінійність була вивчена в діапазоні концентрацій від $1 \cdot 10^{-4}$ до $1 \cdot 10^{-3}$ моль/л. Коефріцієнт кореляції $r=0$, 999. Точність та відтворюваність вивчені шляхом п'ятикратного повторення аналізу для трьох концентрацій. Розраховане стандартне відхилення для усіх концентрацій було менше $1,75 \%, \delta \leq-1,1 \%$. Межа виявлення (MB) $i$ межа кількісного визначення (МКВ) були розраховані (MB $=1,2 \cdot 10^{-5}$ моль/л і МКВ $=4 \cdot 10^{-5}$ моль/л). Встановлено, що запропонована вольтамперометрична методика для визначення лікарського препарату у низькій концентрації $є$ досить чутливою, точною, правильною, відтворюваною $i$ лінійною. Ці переваги дозволяють застосовувати їі для кількісного визначення цефотаксиму в контрольно-дослідних лабораторіях.

\section{ВОЛЬТАМПЕРОМЕТРИЧЕСКОЕ ОПРЕДЕЛЕНИЕ ЦЕФОТАКСИМА С УЧАСТИЕМ КАЛИЯ ГИДРОПЕРОКСОМОНОСУЛЬФАТА \\ Ю.Ю.Лабузова}

Ключевые слова: вольтамперометрия; иефотаксим; калия гидрогенопероксомоносульфат Работа посвящена разработке новой вольтамперометрической методики количественного определения цефотаксима в порошке для приготовления раствора для инъекций по продукту пероксокислотного окисления в виде S-оксида в слабокислой среде с использованием гидропероксомоносульфрата калия $\left(\mathrm{KHSO}_{5}\right)$ как аналитического реагента. Были сняты вольтамперограммы растворов S-оксида цефотаксима для различных концентраций цефралоспорина. Катодная ветка вольтамперограмы раствора S-оксида цефотаксима имеет два пика: при -0,65 В (что соответствует гидропероксомоносульфрату калия) и -1,3 В (высота пика менялась пропорционально изменению концентрации цефотаксима), который выбран как аналитический. Была показана возможность применения метода калибровочного графика. Линейность была изучена в диапазоне концентраций от $1 \cdot 10^{-4}$ до $1 \cdot 10^{-3}$ моль/л. Коэффрициент корреляции $r=0$,999. Точность и воспроизводимость изучены путем пятикратного повторения анализа для трех концентраций. Рассчитанное стандартное отклонение для всех концентраций было меньше 1,75\%, $\delta \leq-1,1 \%$. Предел обнаружения (ПО) и предел количественного определения (ПКО) были рассчитаны (ПО = 1,2·10-5 моль/л и ПКО $=4 \cdot 10^{-5}$ моль/л). Установлено, что предложенная вольтамперометрическая методика для определения лекарственного препарата при низкой концентрации является чувствительной, точной, правильной, воспроизводимой и линейной. Эти преимущества позволяют применять ее для количественного определения цефротаксима в контрольно-исследовательских лабораториях. 